\title{
Original article (short paper) \\ The influence of the external ankle support on the dynamic balance in volleyball athletes
}

\author{
Manuela Azevedo Correia de Lima \\ Germanna de Medeiros Barbosa \\ Joseanne Daniele Cezar Ribeiro \\ José Jamacy de Almeida Ferreira \\ Palloma Rodrigues de Andrade \\ Heleodório Honorato dos Santos \\ Universidade Federal da Paraíba, João Pessoa, Brazil
}

\begin{abstract}
The purpose of this study was to assess the effect of ankle external supports on proprioception and dynamic balance in volleyball players. Seventeen female volleyball players $(18.94 \pm 2.49$ years; $65.45 \pm 9.49 \mathrm{~kg} ; 1.71 \pm 0.05 \mathrm{~m}$; $\mathrm{BMI}=22.0 \pm 2.67 \mathrm{~kg} / \mathrm{m}^{2}$ ) took part in this study. The dynamic balance was assessed through the Star Excursion Balance Test (SEBT). Comparisons between stabilization (no stabilizer/NS, orthosis/ORT and functional bandaging/FB) modes and the SEBT grid lines and inter-limb were carried out. The SEBT assessment showed a significant difference between the groups NS x ORT and NS x FB $(p<.01)$, and between the lines $(p<.01)$. Significant line/limb interaction in DL and NDL $(p<.01)$ was detected. The external supports tested herein showed similar effects on balance, restricting lower limb's reach in the SEBT execution in some of tested directions.
\end{abstract}

Keywords: athletic injuries, secondary prevention, stabilization, movement

Resumo - “A influência do suporte externo de tornozelo na dinâmica do equilíbrio em atletas de voleibol.” O propósito deste estudo foi avaliar o efeito de suportes externos de tornozelo na propriocepção e equilíbrio dinâmico em atletas de voleibol. Dezessete atletas de voleibol $\left(18,94 \pm 2,49\right.$ anos; $\left.65,45 \pm 9,49 \mathrm{~kg} ; 1,71 \pm 0,05 \mathrm{~m} ; \mathrm{IMC}=22,0 \pm 2,67 \mathrm{~kg} / \mathrm{m}^{2}\right)$ foram analisadas. O equilíbrio dinâmico foi avaliado por meio do Star Excursion Balance Test (SEBT). Comparações foram realizadas entre os modos de estabilização (Sem Estabilizador/SE, Órtese/ORT e Bandagem Funcional/BF) e as linhas da grade do SEBT e comparação inter-membros. A avaliação do SEBT mostrou diferença significativa entre os grupos $(p<0,01)$, SE x ORT e SE x BF e entre as linhas $(p<0,01)$, além de interação linha/membro, no MD e MND $(p<0,01)$. Os suportes externos testados (ORT e BF) se comportaram de forma semelhante, restringindo o alcance do membro inferior na execução do SEBT em algumas das direções testadas.

Palavras-chave: lesões em atletas, prevenção secundária, estabilização, movimento

Resumen- -A influencia do suporte externo de tobillo na dinámica do equilibrio en atletas de voleibol." El propósito de este estudio fue evaluar el efecto de los apoyos externos de tobillo en la propiocepción y el equilibrio dinámico en atletas de voleibol. Diecisiete jugadores de voleibol $(18,94 \pm 2,49$ años; $65,45 \pm 9,49 \mathrm{~kg}, 1,71 \pm 0,05 \mathrm{~m}$, IMC=22,0 $\pm 2,67$ $\mathrm{kg} / \mathrm{m}^{2}$ ). El equilibrio dinámico fue evaluado por el Star Excursion Balance Test (SEBT). Comparación de los modos de estabilización (Si Estabilizador/SE, Ortesis/ORT y Vendaje Funcional/VF) y las líneas de cuadrícula SEBT, y intermiembros se fuera realizado. Evaluación del SEBT mostró una diferencia significativa entre los grupos $(p<0,01)$, SE x ORT, SE x BF y entre líneas $(p<0,01)$, además de la interacción línea/miembro en el MD y MND $(p<0,01)$. Los medios de estabilización externa probados (ORT x BF) se comportaron de manera similar, lo que restringe el alcance de las extremidades inferiores en la ejecución del SEBT en algunas de las direcciones probadas.

Palabras claves: traumatismos en atletas, prevención secundaria, estabilización, movimento

\section{Introduction}

Ligament injuries or ankle sprains frequently occur in activities of daily living (ADL) or in sports, corresponding to about $10 \%$ to $15 \%$ of all sport injuries, especially soccer, basketball and volleyball players (Rodrigues \& Waisberg, 2009). According to Meurer, Pacheco, Pacheco, and Silva (2010), because the lateral collateral ligament complex is weaker and less numerous than medial ligaments and the fibula extending more distally than the tibia, a high incidence of inversion sprains occurs, corresponding to approximately 80 to $90 \%$ of all ankle sprains. Also, in volleyball, ankle sprains emerge as the most frequent injury (Cardoso et al., 2005) totaling from $15 \%$ to $60 \%$ of all injuries (Fortes \& Carazzato, 2008; 
Ingham, Alloza, Cohen, Nery, \& Chamlian, 2007) and the main risk factors are landing and jumps connected to blocking and attack skills (Fortes \& Carazzato, 2008).

To Hubbade, Kramer, Denegar, and Hetel (2007), recurring sprains cause postural damage to ligaments, thus decreasing the sensations related to muscular strength, movement and joint position. Supporting this hypothesis, Sawkins, Refshauge, Kilbreath, and Raymond (2007) claim that ligament injuries cause tears in joint nerve fibers and a reduction of sensory input of the mechanoreceptors. In this way, individuals with mechanical instability, along with ligament laxity, certainly have some postural deficit.

In the search for prevention of these injuries, the use of techniques such as functional bandaging, ankle bands and orthosis became increasingly common in the attempt to reduce their incidence and recurrence (Dizon \& Reyes, 2010). Epidemiologic studies (Dizon \& Reyes, 2010; Silva \& Gonçalves, 2007) showed decrease in ankle injuries with the use of an external support aid during the practice of sports.

Various instruments and tests (Functional Reach Test, force plate, isokinetic dynamometer, figure-of-8-hop, side hop, updown-hop, single hop, triple hop test, etc.) have been utilized to assess dynamic balance and proprioception (Almeida, 2007; Gear, Bookhout, \& Solyntjes, 2011; Lobato, et al., 2005; Takahashi et al., 2006; Suda \& Souza, 2009; Wieczorek, 2003). Recently, researchers begun to use the Star Excursion Balance Test (SEBT) to simultaneously assess dynamic balance (Gribble \& Hertel, 2003), the ankle's range of motion/ROM (Olmsted, Caria, Hertel, \& Shultz, 2002), and the proprioceptive activation level (Plisky et al., 2009). SEBT showed good to excellent intra- and inter examiner reliability in the measurement of functionality (Suda \& Souza, 2009) and asymmetries, assisting in the decision-making process for rehabilitation and release of athletes in a variety of sports. Additionally, the SEBT can be utilized to assess physical performance, but also to trace dynamic postural-control deficits due to musculoskeletal injuries such as chronic ankle instability (Plisky et al., 2009).

Therefore, since no scientific evidence has been found that points out which of the external supports (functional bandaging or orthosis) is most effective in ankle proprioceptive activation and corporal stabilization in volleyball players, the purpose of this study was to assess the use of ankle orthosis and functional bandaging in proprioceptive activation and dynamic balance in volleyball players using the SEBT.

\section{Methods}

\section{Study design and sample}

This study is characterized as a quantitative transversal approach study carried out at the Laboratory of Biological Signs of the Human Movement Centre, from the Federal University of Paraíba (UFPB), Brazil.

The sample was selected for convenience, satisfying the following criteria for inclusion: volleyball players, female, between 18 and 24 years of age, participation in at least one of the Brazilian College Olympic Games and that show no previous history of orthopedic injury (including ankle sprains for at least 6 months), cardiovascular, metabolic and/or vestibular dysfunctional and neurologic dysfunctional disorders. Furthermore, they should have more than 1 year of training and practice at least 3 times a week.

Initially 22 volunteers (18.94 \pm 2.49 years; $65.45 \pm 9.49 \mathrm{~kg}$; $1.71 \pm 0.05 \mathrm{~m}$; and a Body Mass Index/BMI of $22 \pm 2.67 \mathrm{~kg} / \mathrm{m}^{2}$ ) were selected, however only 17 completed the study, as shown in Figure 1. Each one of them was assessed by the SBET, utilizing 3 randomly (www.lee.dante.br) distributed ankle stabilization conditions: 1) No stabilizer/NS; 2) use of orthosis/ORT (Active Ankle Systems - Louisville, KY - USA); and 3) with the use of functional bandaging/BF (adhesive tape - Cremer, Brazil, associated with pre-tape Underwrep - Mueller, EUA).

The sample size was determined using the G*Power 3.1.0 software and the procedures followed the recommendations of Beck (2013). Based on an a priori analysis, we adopted a potency of $0.80, \alpha=.05$, coefficient of correlation of .5 , non-sphericity correction of 1 and an effect size of .35. For all groups, an " $n$ " of 15 subjects was calculated. This preliminary analysis of the statistical power was conducted to reduce the type II error probability, and to determine the minimal number of subjects necessary for this investigation. The sample size was confirmed to be sufficient to provide $80.03 \%$ statistical power; however, the post-hoc analysis showed that 17 participants represent 85.92 of the statistical power.

The study was approved by the Health and Science Center Research Ethics Committee at the Federal University of Paraíba (CEP/CCS/UFPB), under the protocol 017/13, CAAE: 11963712.5.0000.5188. All subjects were instructed about the study and signed an Informed Consent Form, agreeing to their participation, according to resolution 466/12 of the National Health Council (NHC) of Brazil and Helsinki Declaration.

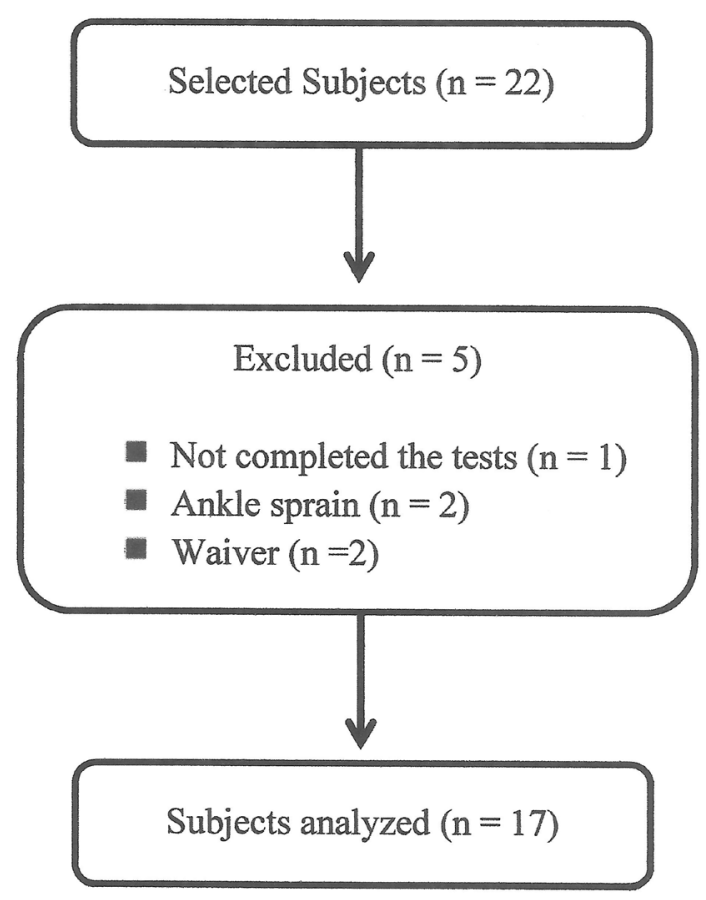

Figure 1. Research design. 


\section{Procedures}

Firstly, the same examiner carried out the clinical functional assessment (anamnesis; physical exam - inspection, palpation, muscular conditions, mobility and special tests), immediately after, the dominance of the limbs (arm and foot that controls the ball) was determined and anthropometric data of each volunteer was registered. Then, the clinical assessment of the ankle and hind foot using the American Orthopaedic Foot and Ankle Society (AOFAS) test - comprised of nine items, distributed in three categories: pain (40 points), functional aspects (50 points) and alignment (10 points), with a total score of 100 points indicating a normal score.

\section{Star Excursion Balance Test (SEBT)}

To perform the SEBT, a grid was prepared with 8 lines constructed with colored cardstock ( $1 \mathrm{~m}$ length and $5 \mathrm{~cm}$ wide) stuck to the ground with double-side adhesive tape, maintaining a $45^{\circ}$ angle between them (Figure 2). Each of the eight lines was measured with a metric tape and the examiner made smaller demarcations, each 1-centimeter, and larger ones each 5 centimeters, to facilitate visualization of the distance reached during the execution of the test and identified (Olmsted et al., 2002).

The identification of the line could vary according to the supporting limb (assessed) because the anatomical reference became the opposite lower limb (ex: the medial line for the lower right limb becomes the lateral line for the lower left limb).

For the test execution, the starting position was a single-leg stance on the lower limb under assessment. The volunteer was instructed to try to reach the farthest distance possible on the chosen line and touch it with the distal end of the foot, as smoothly as possible, in order to prevent excessive weight transfer to the other foot, maintaining body stability and returning to the starting position.

Immediately after, the examiner always recorded the greatest distance (in centimeters) along the line from the center of the grid until the touch point of the foot (Figure 2) reached by the volunteer.

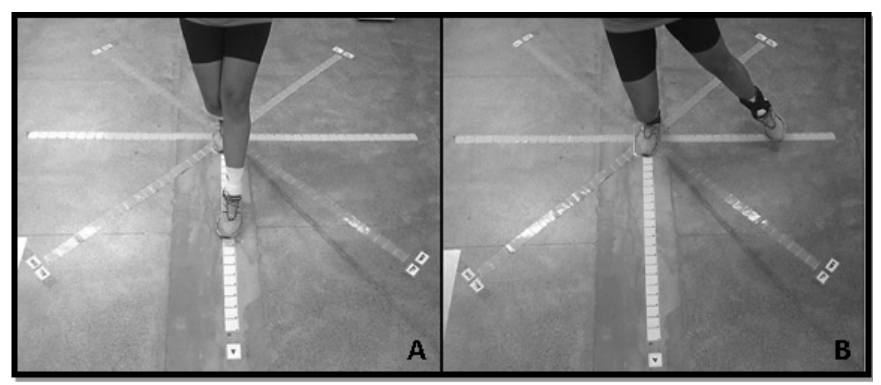

Figure 2. Execution in grid SEBT for dominant limb in the anterior (A) and medial (B) positions, considering the right lower limb.

The examiner carried out verbal and visual demonstrations of the test execution for each athlete. Additionally, each athlete performed three practice trials for each limb in all eight directions in order to familiarize themselves with the task and the procedure. After 5 minutes rest period, the participants executed three trials under the single-leg stance on the dominant limb (DL) and non-dominant limb (NDL) in each of the eight directions, already measured by the examiner. The assessed athlete rested for 15 seconds between each trial. For test standardization, the assessed athletes started at the previous direction and progressed clockwise around the grid. The test execution for each type of external support happened on separate days, with 48-hour intervals between them.

The SEBT record was discarded and repeated in cases where the examiner perceived the imbalance, characterized by a touch with weight transfer to the other foot or removal of the support foot (even partially) from the middle of the grid. For purposes of statistical analysis, it was considered the average of the three trials.

\section{Data analysis}

The statistical procedures were conducted using the software Statistical Package for the Social Sciences (SPSS - 20.0). Initially, data normality (Shapiro-Wilk) and homogeneity of variance (Levene) were calculated, followed by ANOVA (two-way) and Tukey post hoc tests for intergroup (NS, ORT e FB) and interline (A, AM, AL, M, L, PM, PL, $\mathrm{P})$ comparisons. For the inter-limb analysis (dominant and non-dominant), a Student $t$ test (independent) was calculated, considering the significance level of $5 \%$ for all the comparisons.

\section{Results}

The selected athletes were specialized in one of the five game volleyball positions as follow: setter $(11.77 \%)$, libero (5.89\%), middle blocker $(17.64 \%)$, opposite $(41.17 \%)$ and right side hitter $(23.53 \%)$.

The dominance found in the limbs was predominantly the right $(88.22 \%)$ and the clinical criteria of AOFAS for assessment of the ankle and the hind foot showed an average score of 95.12 points in their ankle and feet.

Analysis of variance (ANOVA) showed that, when compared to the distances normalized by the length of the lower limb reached in the SEBT, there was a significantly statistical difference between the groups (NS, ORT and FB: $p<.01$ ), between the lines (A, AM, AL, M, L, P, PM, PL: $p<.01)$, along with line/limb interaction, in DL as well as in NDL $(p<.01)$.

The multiple comparison Tukey post hoc test showed a significant difference between the groups: NS x ORT (DL: $p<.026$; NDL: $p=.003$ ) and NS x FB (DL: $p=.015$; NDL: $p=.041)$, in which the NS group reached the average distance in the SEBT, however no significant difference was found for the comparison between ORT and FB groups $(p=.834)$. 
Table 1. Average values in SEBT, normalized by the length of the lower limb (\%) of each participant.

\begin{tabular}{ccccccc}
\hline \multirow{2}{*}{ Lines } & \multicolumn{2}{c}{ NS } & \multicolumn{2}{c}{ ORT } & FB \\
\cline { 2 - 7 } & DL & NDL & DL & NDL & DL & NDL \\
\hline A & $0.67 \pm 0.05$ & $0.68 \pm 0.06$ & $0.66 \pm 0.05$ & $0.65 \pm 0.05$ & $0.64 \pm 0.06$ & $0.65 \pm 0.08$ \\
AL & $0.56 \pm 0.06$ & $0.58 \pm 0.08$ & $0.53 \pm 0.04$ & $0.55 \pm 0.08$ & $0.49 \pm 0.06$ & $0.57 \pm 0.09$ \\
L & $0.51 \pm 0.07$ & $0.52 \pm 0.12$ & $0.46 \pm 0.03$ & $0.48 \pm 0.12$ & $0.47 \pm 0.05$ & $0.50 \pm 0.11$ \\
PL & $0.64 \pm 0.09$ & $0.66 \pm 0.08$ & $0.60 \pm 0.10$ & $0.62 \pm 0.09$ & $0.59 \pm 0.09$ & $0.63 \pm 0.11$ \\
P & $0.71 \pm 0.09$ & $0.71 \pm 0.08$ & $0.69 \pm 0.10$ & $0.66 \pm 0.10$ & $0.69 \pm 0.11$ & $0.68 \pm 0.10$ \\
PM & $0.71 \pm 0.09$ & $0.70 \pm 0.09$ & $0.69 \pm 0.09$ & $0.64 \pm 0.09$ & $0.70 \pm 0.10$ & $0.67 \pm 0.10$ \\
M & $0.72 \pm 0.08$ & $0.70 \pm 0.14$ & $0.72 \pm 0.07$ & $0.65 \pm 0.12$ & $0.73 \pm 0.09$ & $0.66 \pm 0.14$ \\
AM & $0.70 \pm 0.06$ & $0.67 \pm 0.08$ & $0.69 \pm 0.05$ & $0.64 \pm 0.08$ & $0.69 \pm 0.06$ & $0.64 \pm 0.09$ \\
\hline
\end{tabular}

Legend: $\mathrm{NS}=$ no stabilizer; $\mathrm{ORT}=$ orthosis; $\mathrm{FB}=$ functional bandaging; $\mathrm{A}=$ anterior; $\mathrm{AL}=$ anterolateral; $\mathrm{L}=$ lateral; $\mathrm{PL}=$ posterolateral; $\mathrm{P}=$ posterior; $\mathrm{PM}=$ posteromedial; $\mathrm{M}=$ medial; $\mathrm{AM}=$ anteromedial.

In general (Table 1), the NS group reached the highest average distances than did the ORT or FB groups and that in the directions P, PM, M and AM, the highest averages were reached.

In terms of the distance comparisons between the SEBT grid lines, the Tukey post hoc test also showed that there was a significant difference in the majority of comparisons $(p<.01)$. In the DL, these differences were more evident in the directions: A, AL and PL, while in NDL, in the directions $\mathrm{AL}$ and $\mathrm{L}$.

In terms of the inter-limb comparisons (DL x NDL), the Student (independent) $t$ test only showed the significantly difference in the AM direction of the ORT group $(p=.024)$ and in the directions AL and AM of the FB group ( $p=.035 \mathrm{e}$ $p=.018$. respectively), however no difference was found in the group without a stabilizer.

\section{Discussion}

In general, our results showed two important findings: 1) similar behavior in the stabilization reached by dynamic orthosis use and, e 2) the SEBT's sensitivity in detecting these findings. In both groups there was a reach restriction obtained in the SEBT execution promoted by the stabilization of these two types of external ankle stabilizers.

Aguiar and Méjia (2012) argue that a decrease in the SEBT efficiency occurs in function of the reduction in range of motion (ROM) imposed by the use of these external supports.

Silva and Gonçalves (2007) explain that the mechanism action of the semi-rigid orthosis and functional bandaging is related to the ankle's ROM prophylactic limitation. Perhaps, this explain the limited use of stabilizers, whereas the SEBT execution in the most diverse requires inversion and/or eversion movements from the support limb, associated with the ankle's dorsiflexion in a closed kinetic chain.

Cordova, Ingersoll, and LeBlanc (2000), in a review analyzing 19 studies about the limitations imposed by the use of external stabilizers, concluded that ankle orthosis predominantly limited inversion and eversion movements, while the functional bandaging limited the dorsiflexion. Previous studies showed the limited effect of orthosis on dynamic stability (Cordova et al.,
2000; Cordova, Ingersoll, \& Palmieri, 2002; Eils et al., 2002; Jerosch, Hoffstetter, Bork, Bischof, 1995) due to the detected reduction of ankle ROM associated with their use.

Corroborating the results of this study, Silva and Gonçalves (2007) claimed that the limitation of ankle movements on the sagittal plane (dorsiflexion and plantar flexion) caused by the use of bandages could, at the same time, alters the shock absorption, shifting from the ideal position for initial contact, and providing greater instability in the dynamic balance and therefore, leading to a shorter distanced reached by the SEBT.

As for the inter-limb reach comparisons (DL x NDL), in which differences were only found in one direction, $A M$ of the ORT group in the directions $\mathrm{AL}$ and $\mathrm{AM}$ of the group $\mathrm{FB}$, the study of Gribble and Hetel (2003) agrees, in part, with this study's results. In general, there were no relevant reach differences found between the young subjects' limbs, utilizing the SEBT.

In this study, the lines M, PM and P provided greater reaches, while line $\mathrm{L}$ had the shortest reach. Partially confirming these results, Gribble and Hetel (2003), and Hardy, Huxel, Brucker, and Nesser (2008) found that the SEBT range was greater in the directions $\mathrm{P}$ and $\mathrm{M}$, and shorter in the directions $\mathrm{A}$ and $\mathrm{L}$. This result can be attributed to the ease of the movement of the lower limb suspended in the directions P and M. In this situation, the limb is free to carry out the task. Due to the greater difficulty to move in directions $\mathrm{A}$ and $\mathrm{L}$ associated to the limiting position of the lower support limb, and according to Hoch, Staton, and McKeon (2011), a longer range of dorsiflexion is required for the execution of the SEBT in line A.

Some studies analyzing effects of orthosis and bandages on ankle stabilization generated discussions about whether these types of external ankle stabilizers interfere or not with the functional performance of an athlete without a history of injuries. Cordova et al. (2002), assessing the effects of external supports on ROM of the foot and ankle, concluded that the semi-rigid orthosis and the functional bandaging restrict the ROM of healthy individuals, causing a functional reduction for the execution of various dynamic activities.

Callaghan (1997), in a literature review about the effects of various ankle supports on swelling, stability, ROM, proprioception, muscular function, walking and performance tests, observed that the use of rigid and non-rigid orthosis on athletes 
who are not seriously injured significantly reduces ankle movement, especially the inversion.

In a study that analyzed performance in some basketball movements, using some types of external supports (Swede-OUniversal. Active Ankle and Aircast), Mckean, Bell, and Burnham (1995) verified that the tested supports caused functional damage. These supports appear to be more effective for the prevention of ankle sprains and for avoiding injury reoccurrence in high-risk sports. However, their prophylactic effects were not very clear.

On the other hand, the majority of studies did not show significant effects from the external supports on the subjects' performance. Hardy et al. (2008), analyzing the effect of ankle orthosis (including the Active Ankle) on the SEBT performance in healthy individuals, reported that there were not significantly different in comparisons of the averages of the distances with and without a stabilizer use. However, the sample consisted of men and women, with a larger quantity of participants $(n=36)$ than used in the present study.

Corroborating the results of this study, Ozer, Senbursa, Baltaci, and Hayran (2009) evaluated the effects of bracing and banding on functional balance, jumping performance, coordination and proprioception. They found no significant difference between these two types of stabilizers, but claimed that both play an important role in preventing or rehabilitating ankle injuries.

Conversely, Gear et al. (2011) analyzed the ankle dynamic stability with participants barefoot, taping and bracing (Swede-O, Inc., North Branch, MN - USA). Twenty one young healthy participants were assessed using Biodex Balance System and the scores of perceived stability (Likert scale) and results showed that, although the tape show a sense of stability compared to barefoot brace condition, there was no statistical difference between the three conditions. Stability index measured by the balance platform indicated that ankle taping and bracing showed not effect on overall dynamic balance in healthy participants.

Santos, McIntire, Foeking, and Liu (2004) claimed that the limitation of ankle movement could lead to an increase of the overload of adjacent joints and risk of injury. In this sense, Silva and Gonçalves (2007) claimed that the restricted movement in a single direction could affect the performance and offer a certain risk of injury. Therefore, the use of the orthosis for prophylactic purposes on a healthy athlete should be carefully considered.

On this same line, Aguiar and Méjia (2012) argue that the semi-rigid orthosis, as well as the bandage, can be used by individuals with instability, with the purpose of preventing sprains because they provide stability to joints, limiting excessive ranges, improving postural input and accelerating neuromuscular response facing a risky situation. However, in healthy individuals, ankle stabilizers should be used cautiously since in these cases a reduction in functional performance can really occur.

Some limitations in this study should be considered: 1) few studies compare the types of external ankle supports and their influence on proprioception in healthy individuals, especially, making use of the SEBT as an assessment tool; 2) the fact that the dynamic balance tested in the SEBT does not work the same way in intense athletic activities, such as running or jumping. Therefore, it would be important to use dynamic functional tests, which could have reflected the athletic performance with the utilization of the orthosis and functional bandaging.

\section{Conclusion}

The results of the study allow concluding that the external tested supports (orthosis and functional bandaging) affected similarly the ankle stabilization, regardless the analyzed lower limb. The distance reduction reached by the athletes in the SEBT in the A, AL, L and PL directions, possibly, in virtue of the restricted dorsiflexion, inversion and eversion movements, promoted ankle stabilization.

However, more studies on the true effectiveness of these implements are necessary for the proprioceptive activation dynamic balance of healthy subjects, to clarify the action of possible physiological and biomechanical mechanisms in specific activities of each sport, making the selection process of preventative measures for athletes clear.

\section{References}

Aguiar, J.P., \& Méjia, D.P.M. (2012). A interferência do uso da órtese e da bandagem no desempenho esportivo de indivíduos com instabilidade de tornozelo: uma revisão de literatura (monografia de Especialização em Fisioterapia Traumato-ortopédica com ênfase em Terapia Manual). Faculdade Ávila. Goiânia, Góias, Brasil.

Almeida, S.T. (2007). Análise da estabilidade postural de idosos sedentários, praticantes de exercício físico regular e atletas. Revista Brasileira de Ciência e Envelhecimento Humano, 4, 39-47. Retrieved from: http://www.upf.br/seer/index.php/rbceh/article/ view/115/90.

Beck T.W. (2013). The importance of a priori sample size estimation in strength and conditioning research. Journal of Strength and Condition Research, 27, 2323-2337. doi:10.1519/ JSC.0b013e318278eea0.

Callaghan, M.J. (1997). Role of ankle taping and bracing in the athlete. Bristh Journal of Sports Medicine, 31, 102-108. doi:10.1136/ bjsm.31.2.102.

Cardoso, J.R., Guerino, C.S.M., Santos, M.B., Mustafá, T.A.D.A., Lopes, A.R., \& Paula, M.C. (2005). Influência da utilização da órtese de tornozelo durante atividades do voleibol: avaliação eletromiográfica. Revista Brasileira de Medicina do Esporte. 11, 276-280. Retrieved from: http://www.scielo.br/pdf/rbme/ v11n5/27588.pdf.

Cordova, M.L., Ingersoll, C.D., \& LeBlanc, M.J. (2000). Influence of ankle support on joint range of motion before and after exercise: a meta-analysis. Journal of Orthopaedic \& Sports Physical Therapy, 30, 170-182. doi:10.2519/jospt.2000.30.4.170.

Cordova, M.L., Ingersoll, C.D., \& Palmieri, R.M. (2002). Efficacy of prophylactic ankle support: an experimental perspective. Journal of Athletic Training, 37, 446-457. Retrieved from: http://www. ncbi.nlm.nih.gov/pmc/articles/PMC164376.

Dizon, J.M.R., \& Reyes, J.J.B. (2010). A systematic review on the effectiveness of external ankle supports in the prevention of inversion 
ankle sprains among elite and recreational players. Journal of Science and Medicine in Sport, 13, 309-317. doi:10.1016/j. jsams.2009.05.002.

Eils, E., Demming, C., Kollmeier, G., Thorwesten, L., Völker, K., \& Rosenbaum D. (2002). Comprehensive testing of 10 different ankle braces: evaluation of passive and rapidly induced stability in subjects with chronic ankle instability. Clinical Biomechanics, 17, 526-535. doi:S0268-0033(02)00066-9.

Fortes, C.R.N., \& Carazzato. J.G. (2008). Estudo epidemiológico da entorse de tornozelo em atletas de voleibol de alto rendimento. Acta Ortopédica Brasileira, 16, 142-147. Retrieved from: http:// www.scielo.br/pdf/aob/v16n3/a03v16n3.pdf.

Gear, W.S., Bookhout, J.L., \& Solyntjes, A.L. (2011). Effect of ankle taping and bracing on dynamic balance and perception of stability. International Journal of Exercise Science, 5, S13-14. Retrieved from: http://digitalcommons.wku.edu/ijesab/vol5/iss2/6.

Gribble, P.A., \& Hertel, J. (2003). Considerations for normalizing measures of the Star Excursion Balance Test. Measurement in Physical Education and Exercise Science, 7, 89-100. Retrieved from: http:// www.udel.edu/bioms/seminararchives/05_06/Gribble.pdf.

Hardy, L., Huxel, K., Brucker, J., \& Nesser, T. (2008). Prophylactic ankle braces and Star Excursion Balance measures in healthy volunteers. Journal of Athletic Training, 43, 347-351. Retrieved from: http://natajournals.org/doi/pdf/10.4085/1062-6050-43.4.347.

Hoch, M.C., Staton, G.S., \& McKeon, P.O. (2011). Dorsiflexion range of motion significantly influences dynamic balance. Journal of Science and Medicine in Sports. 14, 90-92. doi:10.1016/j. jsams.2010.08.001.

Hubbard, T.J., Kramer, L.C., Denegar, C.R., \& Hetel, J. (2007). Correlations among multiples measures of functional and mechanical instability in subjects with chronic ankle instability. Journal of Athletic Training, 42, 361-366. Retrieved from: http://www.ncbi. nlm.nih.gov/pmc/articles/PMC1978473.

Ingham, S.J.M., Alloza, J.F.M., Cohen, M., Nery, C.A.S., \& Chamlian, T.R. (2007). Torções de tornozelo em atleta feminina de voleibol. Revista Medicina e Reabilitação, 26, 25-29. Retrieved from: http:// bases.bireme.br/cgi-bin/wxislind.exe/iah/online/?IsisScript=iah/ iah.xis\&src $=$ google \&base $=$ LILACS\&lang $=$ p\&nextAction $=\operatorname{lnk} \&-$ exprSearch $=461344 \&$ indexSearch=ID.

Jerosch, J., Hoffstetter, I., Bork, H., Bischof, M. (1995). The influence of orthoses on the proprioception of the ankle joint. Knee Surgery Sports Traumatology and Arthroscopy, 3, 39-46. Retrieved from: http://download.springer.com/ static/pdf/433/art\%253A10.1007\%252FBF01553524.pdf?auth66=1392574586_6948509963a00f63716957cfffba0cd5\&ext $=$. pdf.

Lobato, D.F.M., Santos, G.M., Coqueiro, K.R.R., Mattiello-Rosa, S.M.G.

Terruggi-Junior, A., Bevilaqua-Grossi, D., ...Monteiro-Pedro, V. (2005). Avaliação da propriocepção do joelho em indivíduos portadores de disfunção femoro-patelar. Revista Brasileira de Fisioterapia, 9, 57-62. Retrieved from: http://www.rbf-bjpt.org. br/files/v9n1/v9n1a08.pdf.
Mckean, L.C., Bell, G., \& Burnham, R.S. (1995). Prophylactic ankle bracing versus taping effects on functional performance in female basketball players. Journal of Orthopaedic \& Sports Physical Therapy, 22, 77-81. doi:10.2519/jospt.1995.22.2.77.

Meurer, M.C., Pacheco, A.M., Pacheco I, \& Silva, M.F. (2010). Análise da influência da bandagem funcional de tornozelo no tempo de reação do fibular longo em sujeitos saudáveis. Revista Brasileira de Medicina do Esporte, 16, 196-200. Retrieved from: http://www. scielo.br/pdf/rbme/v16n3/08.pdf.

Olmsted, L., Caria, C., Hertel, J., \& Shultz S. (2002). Efficacy of the star excursion balance tests in detecting reach deficits in subjects with chronic ankle instability. Journal of Athletic Training, 37, 501-506. Retrieved from: http://www.ncbi.nlm.nih.gov/pmc/ articles/PMC164384.

Ozer, D., Senbursa, G., Baltaci, G., \& Hayran M. (2009). The effect on neuromuscular stability, performance, multi-joint coordination and proprioception of barefoot, taping or preventative bracing. The Foot, 19, 205-210. doi: 10.1016/j.foot.2009.08.002.

Plisky, P., Gorman, P.P., Butler, R.J., Kiesel, K.B.,Underwood, F.B., \& Elkins, B. (2009). The reliability of an instrumented device for measuring components of the star excursion balance test. North American Journal of Sports Physical Therapy, 4, 92-99. Retrieved from: http://www.ncbi.nlm.nih.gov/pmc/articles/PMC2953327.

Rodrigues, F.L., \& Waisberg, G. (2009). Entorse de tornozelo. Revista da Associação Médica Brasileira, 55, 497-520. Retrieved from: http://www.scielo.br/pdf/ramb/v55n5/08.pdf.

Santos, M.J., McIntire, K., Foeking. J., \& Liu, W. (2004). The effects of ankle bracing on motion of the knee and the hip joint during trunk rotation tasks. Clinical Biomechanics, 19, 964-971. doi: S0268-0033(04)00161-5.

Sawkins, K., Refshauge, K., Kilbreath, S., \& Raymond, J. (2007). The placebo effect of ankle taping on ankle instability. Medicine \& Science in Sports \& Exercise, 39, 781-787. doi: 10.1249/ MSS.0b013e3180337371.

Silva, P.B., \& Gonçalves, M. (2007). Suportes de pé e tornozelo: efeitos na biomecânica e na prevenção de lesões desportivas. Motriz, 14, 312-323. Retrieved from: http://www.periodicos.rc.biblioteca. unesp.br/index.php/motriz/article.

Suda, E.Y., \& Souza, R.N. (2009). Análise da performance funcional em indivíduos com instabilidade do tornozelo: uma revisão sistemática da literatura. Revista Brasileira de Medicina do Esporte, 15, 233-237. Retrieved from: http://www.scielo.br/pdf/rbme/v15n3/ a14v15n3.pdf.

Takahashi, T., Ishida, K., Yamamoto, H., Takata, J., Nishinaga M., Doi, Y. \& Yamamoto, H. (2006). Modification of the functional reach test: analysis of lateral and anterior functional reach in community-dwelling older people. Archives of Gerontology and Geriatrics, 42, 167-173. doi:101016/j.archger.2005.06.010.

Wieczorek, S.A. (2003). Equilibrio em adultos e idosos: relação entre tempo de movimento e acurácia durante movimentos voluntários na postura em pé (dissertação de mestrado). Escola de Educação Física e Esporte, Universidade de São Paulo, Brasil. 


\section{Authors' note}

Manuela Azevedo Correia de Lima (manulima a@hotmail.com), Germanna de Medeiros Barbosa (germannamb@gmail.com), and Joseanne Daniele Cezar Ribeiro (joseanne-.daniele@hotmail.com) have a physical therapist degree by the Federal University of Paraíba/ UFPB, João Pessoa, PB, Brazil.

José Jamacy de Almeida Ferreira (jamacy@gmail.com), Palloma Rodrigues de Andrade (pallomandrade@gmail.com), Heleodório Honorato dos Santos (dorioufpb@gmail.com)_are faculty members of the Physical Therapy Department at the Federal University of Paraíba/ UFPB, João Pessoa, PB, Brazil.

\section{Corresponding author}

Heleodório Honorato dos Santos

Av. Mons. Odilon Coutinho, 191/402, Cabo Branco, João Pessoa, PB 58045-120, Brazil.

\section{Acknowledgments}

This work has financial support from the National Council for Scientific and Technological Development of the Brazil (CNPq - Grant call 2010)

Phone: (83) 8750-7708 / 9613-7900

E-mail: dorioufpb@gmail.com

Manuscript received on April 11, 2015

Manuscript accepted on June 7, 2015

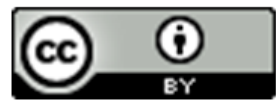

Motriz. The Journal of Physical Education. UNESP. Rio Claro, SP, Brazil - eISSN: 1980-6574 - under a license Creative Commons - Version 3.0 